\title{
PAIN RELIEF DURING LABOR - WHAT DO WE KNOW AND WHAT SHOULD WE KNOW? RESEARCH BASED ON THE STUDENT POPULATION IN WARSAW
}

DOI: 10.36740/WLek202007106

\author{
Martyna Rozek', Zuzann Smiech', Marcin Kolacz' , Dariusz Kosson² \\ II DEPARTMENT OF ANAESTHESIOLOGY AND INTENSIVE CARE, MEDICAL UNIVERSITY OF WARSAW, WARSAW, POLAND \\ ${ }^{2}$ DEPARTMENT OF ANAESTHESIOLOGY AND INTENSIVE CARE, DIVISION OF TEACHING, MEDICAL UNIVERSITY OF WARSAW, WARSAW, POLAND
}

\begin{abstract}
The aim: Women of reproductive age often think of motherhood and labor with fear of intense labor pain. The anxiety they experience can lead to their postponing pregnancy. There are not many studies in the literature that research the knowledge young women have about the analgesia of labor. The aim of the present work was to evaluate the state of awareness about the possible methods of labor analgesia among women of childbearing age.

Material and methods: An Internet survey was conducted among 160 women. It consisted of questions on the pharmacological and non-pharmacological methods of labor analgesia. Most of the respondents were not medical university students (96.2\%). Correct answers ranged between $11.3 \%$ and $97.5 \%$ of the total responses.

Results: The greatest number of incorrect answers were given to the question regarding contraindications to labor anesthesia (only $11.3 \%$ of answers were correct). There was also a low percentage of correct answers to questions about the risk of spinal cord injury during the procedure of inducing anesthesia (18.8\% of correct answers), the motor activity of a woman after analgesia (22.5\%) and the reimbursement of anesthesia (29.4\%). Nearly $40 \%$ of the respondents did not know the correct answer to the question about the possibility of breastfeeding after anesthesia. The problem of aalgesia during twin delivery also posed a challenge. Over half of the respondents (54.1\%) incorrectly answered the question about the occurrence of complications among women who want to become pregnant again after the procedure of labor anesthesia. Moreover, $70.6 \%$ of the women surveyed considered non-pharmacological methods of labor anesthesia to be safer compared to pharmacological analgesia. The most commonly mentioned methods of non-pharmacological labor pain relief included breathing techniques and water birth.

Conclusions: The study shows that women of childbearing potential have an unsatisfactory level of knowledge about labor anesthesia. There is a need to improve the level of health education on this topic.
\end{abstract}

KEY WORDS: anesthesia, knowledge, pregnancy, perinatal care, health education

Wiad Lek. 2020;73(7):1339-1344

\section{INTRODUCTION}

Every woman experiences labor in a unique way. The emotions that are often reported include excitement, fear, anxiety and uncertainty [1]. When women are asked about what they feel during childbirth, one of the most frequently given answers is pain [2]. According to the literature, labor pain can be one of the most painful experiences in the life of a woman [3]. It occurs in almost every woman in labor. Its intensity depends on many factors, such as the weight and birth length of the child, the size of the woman's pelvis, the position during labor and the individual pain threshold of a given woman [4]. There are also research results enumerating additional factors, such as the mental attitude of the mother, the course taken by labor, the level of the fear experienced and cultural features [5].

At this point it is important to provide the definition of pain, in which it is described as an "an unpleasant sensory and emotional experience associated with actual or potential tissue damage" [6]. Labor pain is made up of two components: visceral pain and somatic pain. Visceral pain occurs during the first stage of labor and is due to pressure exerted on the cervix. Somatic pain appears during both the first and the second stage of labor. It is caused by the pressure exerted on the cervix, the vagina and the perineum [7]. The pain experienced during labor impacts the respiratory system of the parturient leading to hyperventilation and an increase in oxygen consumption, which can result in respiratory alkalosis and a lowering of the blood volume transported to the fetus. In addition, pain can lead to a higher release of catecholamines and cortisol into the circulation [8].

Labor pain also has an important informational role about the stage of childbirth [9]. Uterine contractions become cyclical and their intensity gradually increases in duration, which is accompanied by a greater intensity of pain felt by the parturient [10]. It is believed that severe labor pain can have an adverse effect both on uterine function and the state of both the fetus and the mother [11].

In the scientific literature it is underlined that negative emotions felt during labor can lead to fear of the next time 
childbirth would occur and can even lead to giving up becoming pregnant again. Fear of pain during subsequent labor can also increase the risk of postpartum depression [12]. Women of reproductive age report that thinking of motherhood is often accompanied by fear of the excessive intensity of labor pain. Many declare that they would like to avoid this pain and the fear they feel can lead to postponing the time of planning their pregnancy [13]. Not infrequently their experience of happiness and joy due to having a newborn baby is connected with negative emotions due to their memories of labor pain [14]. It is worth underlining that relieving labor pain is a mandatory component of pregnancy management [15]. Scientific studies underline the key importance played by the entire medical team and the childbearing women in alleviating intrapartum pain. Such cooperation guarantees better labor pain management and decreasing the risk of perinatal injuries, both in the mother and the child [14].

The availability of labor analgesia in Poland depends on the region of the country [16]. The methods of relieving labor pain can be divided into two groups. The first one includes three techniques: epidural analgesia, nitrous oxide administered by inhalation or intravenous opioids. Non-pharmacological methods providing pain relief during labor i.e. the second group include transcutaneous electrical nerve stimulation (TENS), breathing techniques, acupuncture, massage, aromatherapy or biofeedback [3].

The kind and safety of the analgesics provided are an important consideration for women of reproductive age and the education of parturients in this field later leads to an increased satisfaction with labor [10, 17]. The Polish scientific literature features few studies researching the knowledge of young women about pain relief during labor. International research revealed that the knowledge about analgesia, including epidural analgesia, is low. [18].

\section{THE AIM}

The aim of the present study was to define the level of knowledge on the pharmacological and non-pharmacological methods of relieving labor pain, particularly the awareness women of childbearing age have about the provision, contraindications, effects and possible complications of labor analgesia. The study also analyzed the factors which women consider when making the decision on the choice of labor analgesia.

The results that have been presented will make it possible for anesthesiologists and obstetricians to enhance their understanding of the fears experienced by pregnant women and will improve their contacts with their patients regarding issues related to the analgesia of labor.

\section{MATERIAL AND METHODS}

A group of students from the student research group called "Arkona" affiliated at the 1st Clinic of Anesthesiology and Intensive Care, Warsaw University of Medicine, created a survey made up of 33 closed questions. The questionnaire was prepared by medical students and anesthesiologists. The selection of questions was supported by professional practice of anesthesiologists. Mini-Delphi was used as the method of structural selection. Its first part concerned socio-demographic data, while the second one consisted of questions regarding the pharmacological and non-pharmacological analgesic methods - with particular emphasis on labor analgesia. The survey was accessible for two months (1 December 2018 - 31 January 2019) to women studying at Warsaw universities on a well-known social media portal. During this time, 165 completed forms were collected. Analysis was conducted using the Fisher Exact Test. The value of $\mathrm{p}<0.05$ was considered to be statistically significant.

\section{RESULTS}

As a result of preliminary analysis, 5 incorrectly filled in questionnaires were rejected. The error was due to a lack of answers to one of the questions, which could have caused statistical calculation issues. Statistical analysis was conducted of the 160 correctly filled out forms. The respondents included solely women, mostly under the age of $25(79.4 \%, \mathrm{n}=127)$. The age between 25 and 35 years old was reported by $20 \%(n=32)$ of the respondents. Only one woman surveyed was over 35 years old. All of the respondents were university students. The majority came from cities with a population of over 150 thousand inhabitants. Such women composed $43.1 \%(n=69)$ of the total number of those surveyed, while $36.9 \%(\mathrm{n}=59)$ came from towns with a population under 150 thousand, and $20 \%(n=32)$ indicated that their place of origin was a village (Table I).

The respondents were mostly women not studying at medical universities $(96.3 \%, n=154)$, with $50 \%(n=80)$ of those surveyed studying at the Warsaw University of Life Sciences. The second most popular school was the University of Warsaw $(28.1 \%, \mathrm{n}=45)$.

Before filling out the survey, the respondents evaluated their knowledge on labor analgesia on a scale of 0 to 10 , with 0 indicating a lack of knowledge and 10 full knowledge of the topic. Both the median and the average of the answers was $4(\mathrm{SD}=2.72)$. Statistically more women under the age of 25 years old evaluated the level of their knowledge on labor analgesia as low $(\leq 3)(\mathrm{p}=0.018)$.

In response to the multiple-choice question concerning the source of their knowledge about labor analgesia, the most frequently indicated answer was the Internet (36\%) as well as friends and family (17\%). It is worth underlining that social media portals (13\%), television, newspapers and books (18\%) were indicated by a higher percentage of the respondents than a doctor $(8 \%)$ or midwife (8\%) (Fig. 1).

As many as $97.5 \%(n=156)$ of those surveyed claimed that labor pain can be relieved by using pharmacological or non-pharmacological methods. A similar number of women over 25 years of age gave the correct answer to this question. $(\mathrm{p}=0.58)$. Out of all those surveyed $47.5 \%$ $(n=76)$ stated that pharmacological measures were safe for the baby. Women under the age of 25 more frequently gave a "yes" answer to this question ( $\mathrm{p}=0.003)$. Regarding the safety of non-pharmacological techniques, $70.6 \%(\mathrm{n}=113)$ thought that they were safe $(\mathrm{p}=0.024)$. This question re- 
Table I. Demographic data.

\begin{tabular}{|c|c|c|c|}
\hline FEATURE & & NUMBER OF WOMEN SURVEYED & [\%] \\
\hline \multirow{3}{*}{ ஜூ } & $<25$ & 127 & 79.4 \\
\hline & $25-35$ & 32 & 20 \\
\hline & $>35$ & 1 & 0.6 \\
\hline \multirow{4}{*}{ 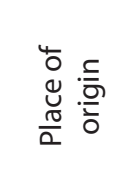 } & City over 150 thousand inhabitants & 69 & 43.1 \\
\hline & Town $50-150$ thousand inhabitants & 17 & 10.6 \\
\hline & Town under 50 thousand inhabitants & 42 & 26.3 \\
\hline & Village & 32 & 20 \\
\hline
\end{tabular}

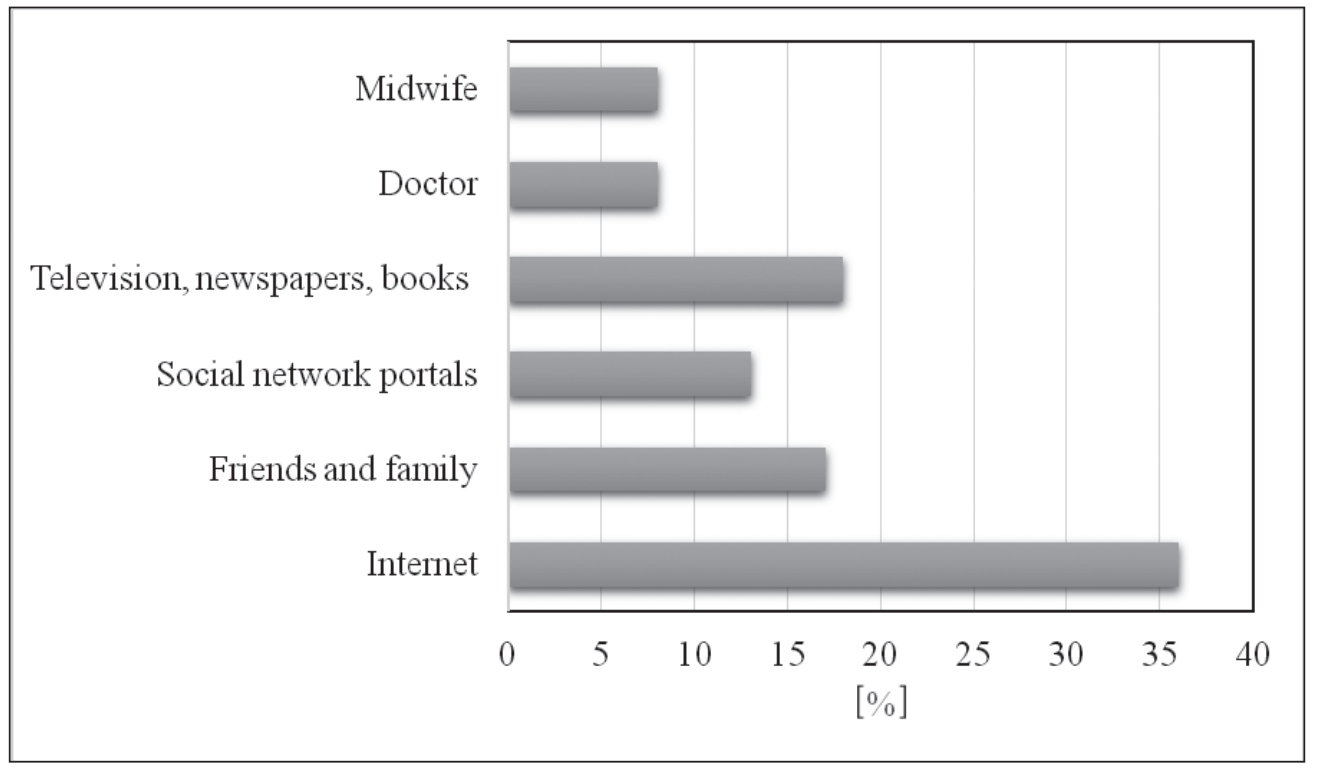

Fig 1. Women's source of knowledge about labor analgesia.

ceived a positive answer from a similar number of women under 25 years old as those over that age $(\mathrm{p}=0.833)$.

The women surveyed were asked to make a hypothetical choice between a pharmacological and non-pharmacological method of intrapartum analgesis. Most of the respondents $(61.9 \%, \mathrm{n}=99)$, decided” in favor of pharmacological analgesis. A similar number of those surveyed aged under and over the age of 25 chose this way of labor aesthesia ( $p=0.844$ ). As many as $94.9 \%$ of those explained the reason for their decision by saying they expected the strongest pain relief effect from this kind of anesthesia. In the group of women who chose the non-pharmacological way of labor pain management the most frequently given reason given for this choice was the low invasiveness of this kind of procedure $(70.5 \%, \mathrm{n}=43)$ and the safety of the child $(21.3 \%, \mathrm{n}=13)$. These reasons were statistically more frequent than in the case of pharmacological anesthesia $(\mathrm{p}<0.001)$.

The next part of the survey concerned knowledge about epidural labor anesthesia. The number of those surveyed that gave a "yes" answer to the question of whether the parturient remains conscious after being provided this kind of anesthesia was $76.9 \%(n=123)$. The respondents were also asked if epidural anesthesia limits the woman's motor activity. Out of all those surveyed $36.9 \%(n=59)$ answered "yes". A lack of knowledge on this topic was declared by as many as $40.6 \%(\mathrm{n}=65)$ of those surveyed $(\mathrm{p}<0.001)$.
The women taking part in the research were also asked about contraindications to epidural analgesia. $11.3 \%(n=96)$ of respondents incorrectly answered the question that possession of tattoos at the site of puncture for epidural anaesthesia is an absolute contraindication for this form of labour analgesia. $60 \%(n=96)$ of the respondents declared that they had no knowledge on this topic, and $28.7 \%(n=46)$ stated that tattoos were not a contraindication to this kind of anesthesia. The respondents were also asked if multiple pregnancy is a contraindication to epidural anesthesia. Only $3.4 \%(n=5)$ of the women incorrectly thought this was a contraindication, while $54.4 \%(n=87)$ declared a lack of knowledge on this topic. The difference between the correct answers to the two above questions was statistically significant $(\mathrm{p}<0.001)$. The next question regarded the age of the parturient. The age over 50 years is not contraindicated for epidural anaesthesia, which was correctly stated by $19.4 \%(n=31)$ of respondents. A lack of knowledge was declared by $59.4 \%(n=95)$ of the respondents and the "yes" answer was given by $21.3 \%(n=34)$ of the women $(p<0,001)$. The survey also included a question on vitro fertilization as a potential contraindication to epidural anesthesia. The number of women who correct stated it was not a contraindication to epidural anesthesia was $58.8 \%$ $(\mathrm{n}=94)$. The rest did not answer this question.

The women surveyed were also asked about the potential complications of epidural labor analgesia. The number of 
Table II. Knowledge of non-pharmacological methods of labor analgesia

\begin{tabular}{cc}
\hline Methods of relieving labor pain & [\%] \\
\hline Water birth & 25 \\
\hline Breathing techniques & 23 \\
\hline Manual methods (massage, hot and cold compresses) & 18 \\
\hline Yoga & 12 \\
\hline Aromatherapy & 9 \\
\hline Acupuncture, acupressure & 8 \\
\hline I do not know any non-pharmacological method of providing pain relief during labor & 4 \\
\hline A TENS unit and transcutaneous electrical nerve stimulation & 0.9 \\
\hline
\end{tabular}

right answers that correctly induced anesthesia can lead to undesirable side effects amounted to $16.9 \%(n=27)$. Out of these respondents, when answering the more specific question regarding the possible complications of epidural intrapartum anesthesia, the greatest number of women $(40.74 \%, n=11)$ incorrectly indicated stopping the progress of labor. Neurological complications, such as paresis and paralysis, were indicated by $29.63 \%(\mathrm{n}=8)$, whereas headaches by $25.93 \%$ $(n=7)$, so the two latter types of problems were thought to occur with similar frequency. The group of respondents foreseeing possible complications of epidural labor analgesia were also asked about the possible complications such anesthesia can lead to neurological disorders in the newborn and potentially - a problem with getting pregnant again. These questions were correctly answered "no" by $81.48 \%(\mathrm{n}=22)$ and $70.37 \%(\mathrm{n}=19)$ of the respondents, respectively $(\mathrm{p}=0.416)$.

Moreover, the respondents had to answer a question regarding other methods of pharmacological anesthesia induced when alleviating intrapartum pain. Out of those surveyed, $48.1 \%(n=77)$ knew that one of such methods can be nitrous oxide in the form of inhalation. Moreover, $13.8 \%(n=22)$ of those surveyed correctly answered "yes", when asked if opioid analgesics can be used $(p<0.001)$.

The respondents were also asked a multiple-choice question on other methods of non-pharmacological anesthesia used for alleviating labor pain (Table II). The most frequently enumerated non-pharmacological methods of labor analgesis turned out to be water birth and breathing techniques. These were indicated by $25 \%$ and $23 \%$ of the respondents, respectively. Only $0.9 \%$ of those surveyed did not know any non-pharmacological method of labor pain analgesia.

\section{DISCUSSION}

According to the ordinance of the Minister of Health dated 9 November 2015 on medical procedure standards in pain management during labor, spontaneous labor analgesia is one of the integral parts of providing this health service and should include all the methods proven scientifically effective [19]. Epidural analgesia is considered the gold standard of providing pain relief during labor [20] respectively. The former revealed that only $47 \%$ of patients had been exposed to the concept of epidural analgesia in labour, and only $13 \%$ opted for such analgesia. In the postnatal cohort, the overall epidural analgesia rate was 10\%, although $19 \%$ had actually requested it. Patients who received epidural analgesia in labour were more likely to consider their experience as favourable (85\%. In spite of the existence of clearly defined guidelines in this filed, our study shows that many women are reluctant to use pharmacological methods of labor analgesia. They often hold scientifically unconfirmed views about dangers connected with using this kind of analgesia. At the same time, it is worth underlining that pregnant women often have no knowledge about the most frequent possible complications of this kind of analgesia. They give consent to anesthesia and obtain the information on the possible complications at a time when the discomfort due to labor makes it difficult for them to remember and analyze new information [21]. The questions we asked our respondents confirm the most common misconceptions about labour anaesthesia. The possession of tattoos at the site of puncture for epidural anaesthesia is not an absolute contraindication to this form of labour analgesia, as is the age of a woman over 50 years old, in vitro fertilization or multiple pregnancy. Contraindications include lack of consent of the patient, lack of cooperation with the patient, blood clotting disorders, shock, skin infection at the puncture site, some diseases of the central nervous system and some heart diseases and defects. Possible complications of epidural delivery anaesthesia include pressure drops, post-punk headaches, temporary pain in the lumbar region of the spine and extremely rare severe neurological complications such as meningitis or epidural hematoma [22].

Research conducted in European countries shows that women's views on pharmacological labor analgesia to a large extent depends on the organization of obstetric care and the opinions held by a given community on the role of pain in natural delivery. If there is a widespread social acceptance of natural delivery analgesia, pregnant women have a better attitude to pharmacological labor anesthesia [23]. In this context, it is worth quoting the results of a Polish survey on women's attitude to natural delivery. Almost half of the respondents indicated that their preferred method of pain relief during labor is epidural analgesia [24]. These results are in line with the data obtained in our study. When asked the question on the hypothetical choice between pharmacological and non-pharmacological pain management methods, over half 
of those surveyed made the decision to use pharmacological methods of analgesia. Perhaps this is due to the belief that this kind of anesthesia is highly effective. Such responses also correspond with the observations of Irish researchers indicating that in the view of pregnant women the availability of pain relief is the most important factor influencing their positive attitude to natural delivery [25].

A survey on a large population of pregnant women in Hong Kong showed a low level of knowledge on the possible methods of relieving labor pain. Knowledge about the possibility to induce epidural anesthesia was definitely less widespread that in the population surveyed in our study, although epidural anesthesia was connected with a more positive experience of labor. It is worth underlining that the availability of this kind of analgesia for the respondents of the Hong Kong study was low, unlike in most European countries, including Poland. It is worth adding that the level of women's knowledge about epidural anesthesia has not changed in a significant way after they had actually experienced natural delivery [18]. This result corresponds with the data quoted above underlining how difficult it is to obtain conscious consent to epidural anesthesia once labor begins.

Research done in developing countries demonstrated a low level of awareness concerning methods of labor analgesia, even if those surveyed were well educated [26, 27]. The women surveyed in these countries often explain that the reason they do not want to have analgesia is because they want to fully experience natural delivery [28]. Such results are in contrast with the data obtained in our study, whose respondents first of all underlined the fear of dangerous complications connected with pharmacologically induced labor analgesia. It is worth adding that women in developing countries indicated that their main source of knowledge about pharmacological methods of labor analgesia was their doctor [29]. On the other hand, the results of our study were quite different. They clearly indicated that the women surveyed more often obtained information from the media, social media, their family and friends than from their doctor or midwife. This can be connected not only with greater access to different sources of information but also the fact that the participants of our survey were exclusively women with an incomplete university education.

To conclude, it is important to note that the pain connected with childbirth can contribute to the number of obstetric failure cases due to mechanisms connected with the increased level of cortisol and hyperventilation as well as respiratory alkalosis [30]. It is worth underlining that the lack of knowledge about the possible methods of labor analgesia and their effectiveness can additionally increase the level of fear and anxiety experienced by the parturient and can disrupt the course of natural delivery [25]. What is more, data from the literature clearly indicate that increasing women's level of awareness about the pharmacological and non-pharmacological methods of alleviating the level of labor pain (in connection with other methods) can lower the number of cesarean sections on demand by as much as $50 \%$. In the group of women who have planned cesarean section on demand, every fourth one would change her mind if she had access to epidural analgesia, while every tenth would make the decision in favor of natural delivery if she could benefit from non-pharmacological methods of relieving labor pain (mostly acupuncture) $[8,9$, 10]. The data quoted in our study prove how important it is for the entire obstetric health care system that the level of pregnant women's awareness of labor pain analgesia in natural delivery should be raised.

Limitations: The study presented included only students studying in Warsaw took part in the presented survey. However, the majority of the respondents were students from only two Warsaw universities. This could have an impact on the extrapolation of the result for the entire population of reproductive-age women in Poland, but also in Warsaw.

\section{CONCLUSIONS}

The research shows that women of reproductive age, studying at Warsaw universities:

1. They have insufficient knowledge about anesthesia for childbirth. The conviction about high efficacy of pharmacological methods of labour anaesthesia, quite common among respondents, is not supplemented by education. In terms of safety, possible side effects and absolute contraindications to the use of these analgesia methods.

2. They consider non-pharmacological methods for the relief of labour pain to be safer but less effective than pharmacological methods.

3. The main sources of knowledge on labour anaesthesia are the media, family and friends. Much smaller physician and midwife.

4. When deciding about the methods of labour pain relief, women are guided by the expected strongest possible analgesic effect, low invasiveness of the procedure and safety of the child.

5. The level of knowledge about analgesia for childbirth is higher in the group of women over 25 years of age. This proves the need to increase the level of health education in labour anaesthesia, particularly in the group of women below 25 years of age, for whom the information on this subject may be particularly important in planning the date of first pregnancy. It should be stressed, however, that only female students of the Warsaw University were subjected to the study.

To sum up, the study demonstrated that in the education of women of childbearing age about labour anaesthesia, the focus should be on exposing the medical personnel as the source of knowledge, emphasizing the knowledge of safety, possible adverse effects and absolute contraindications for labour epidural anaesthesia, especially in women below 25 years of age.

\section{REFERENCES}

1. Kaźmierczak M, Sołdyńska M, Gierszewska M, Gebuza G, Mieczkowska E. Assessment offearin women before childbirth. Nurs Public Heal. 2017;7(1):69-75.

2. KarlsdottirSI,SveinsdottirH,OlafsdottirOA, Kristjansdottir H. Pregnantwomen's expectations about pain intensity during childbirth and their attitudes towards pain management: Findings from an Icelandic national study. Sex Reprod Healthc. 2015 Dec 1;6(4):211-8. 
3. Czech I, Fuchs P, Fuchs A, Lorek M, Tobolska-Lorek D, Drosdzol-Cop A, et al. Pharmacological and non-pharmacological methods of labour pain relief-establishment of effectiveness and comparison. Int J Environ Res Public Health. 2018 Dec 1;15(12).

4. Chutkowsk R, Wódarski B, Malec-Milewska M. Metody i organizacja analgezji porodu - doświadczenia własne. Ból. 2016 Jan 1;16(2):35-43.

5. Dorazil-Dudzik M, Jastrzębska A, Krawczyk P. Leczenie przeciwbólowe w położnictwie i ginekologii zgodne z protokołem ERAS. Med Prakt Ginekol Poloz.. 2018;4:85-92.

6. Lally JE, Murtagh MJ, Macphail S, Thomson R. More in hope than expectation: A systematic review of women's expectations and experience of pain relief in labour. BMC Med. 2008 Apr 14;6:7.

7. Labor $S$, Maguire $S$. Labour is a painful process and is ranked high on the pain rating scale (1). Rev Pain. 2008;2(2):15-9.

8. Koyyalamudi V, Sidhu G, Cornett EM, et al. New Labor Pain Treatment Options. Curr Pain Headache Rep. 2016;20:11

9. Asadi N, Maharlouei N, Khalili A, et al. Effects of LI-4 and SP-6 Acupuncture on Labor Pain, Cortisol Level and Duration of Labor. JAMS J Acupunct Meridian Stud. 2015 0ct 1;8(5):249-54.

10. Smolarek N, Pięt M, Żurawska J, Szpunar R, Pięt B. Alternatywne sposoby łagodzenia bólu porodowego. Pol Przegl Nauk Zdr 2016;1(46):74-80

11. Weigl W, Szymusik I, Borowska-Solonynko A, et al. The influence of epidural analgesia on the course of labor. Ginekol Pol. 2010;81(1):41-5.

12. Majchrzak M, Mika M , Gałązka I, et al. Sposoby łagodzenia bólu porodowego w doświadczeniu położnic. Zdr Dobrost 2014;2:91-98.

13. Bilert H. Tokophobia - a multidisciplinary problem. Ginekol Pol. 2007 0ct;78(10):807-11.

14. Raynes-Greenow CH, Roberts CL, McCaffery K, Clarke J. Knowledge and decision-making for labour analgesia of Australian primiparous women. Midwifery [Internet]. 2007 J;23(2):139-45.

15. Chutkowski R, Wódarski B, Malec-Milewska M. Commentary to Remifentanil for labour pain relief. Anest Intens Ter. 2016;48:7-8.

16. Gałązka M, Gałaś D, Trębacz M, Sieńko-Hans K. Ocena wiedzy kobiet ciężarnych na temat porodu oraz metod łagodzenia bólu porodowego. Pielegniarstwo Pol. 2019;73(3):271-6.

17. Kowalczyk R, Nowacka E. Remifentanyl-zastosowanie w położnictwie. Anest Rat 2012;6:343-349.

18. Karlsdottir SI, Sveinsdottir H, Olafsdottir OA, Kristjansdottir H. Pregnant women's expectations about pain intensity during childbirth and their attitudes towards pain management: Findings from an Icelandic national study. Sex Reprod Healthc [Internet]. 2015 Dec 1;6(4):211-8. A19. Naithani U, Bharwal P, Chauhan SS, Kumar D, Gupta S, Kirti. Knowledge, attitude and acceptance of antenatal women toward labor analgesia and caesarean section in a medical college hospital in India. J Obstet Anaesth Crit Care. 2011;1(1):13-20.

20. To WW. A questionnaire survey on patients' attitudes towards epidural analgesia in labour. Hong Kong Med J. 2007;13:208-15.

21. Dziennik Ustaw Rzeczypospolitej Polskiej. Rozporządzenie Ministra Zdrowia z dnia 9 listopada 2015 r. w sprawie standardów postępowania medycznego przy udzielaniu świadczeń zdrowotnych w dziedzinie położnictwa i ginekologii z zakresu okołoporodowej opieki położniczo-ginekologicznej, sprawowanej nad kobietą w okresie ciąży, porodu, połogu, w przypadkach występowania określonych powikłań oraz opieki nad kobietą w sytuacji niepowodzeń położniczych. 2015;1-18. Available from: [http:// prawo.sejm.gov.pl/isap.nsf/DocDetails.xsp?id=WDU20150002007; cited 2020 May 13].
22. Bręborowicz GH (ed). Położnictwo i ginekologia. vol.1. Warszawa:Wydawnictwo Lekarskie PZWL, 2015, p. 392

23. Misiolek H, Zajaczkowska R, Daszkiewicz A, et al. Postoperative pain management - 2018 consensus statement of the section of regional anaesthesia and pain therapy of the polish society of anaesthesiology and intensive therapy, the polish society of regional anaesthesia and pain therapy, the polish associ. Anest Intens Ter 2018;50:173-99.

24. Frhlich S, Tan T, Walsh A, Carey M. Epidural analgesia for labour: Maternal knowledge, preferences and informed consent. Ir Med J. 2011 Nov;104(10):1-3.

25. Christiaens W, Verhaeghe M, Bracke P. Pain acceptance and personal control in pain relief in two maternity care models: A cross-national comparison of Belgium and the Netherlands. BMC Health Serv Res. 2010;10. Available from: [https://www.ncbi.nlm.nih.gov/ pubmed/20831798; cited 2020 May 13]

26. Njiru JN, Esiromo MA, Omari HO. Knowledge, attitude and use of pain relief in labour among women attending ante-natal clinic at Shalom Community Hospital, Athi River. East Afr Med J [Internet]. 2014 Jul 9;1(7):245-52.

27. Kosińska K, Krychowska A, WielgośM, Myszewska A, Przyboś A. Attitude of pregnant women towards labour--study of forms of preparation and preferences. Ginekol Pol [Internet]. 2005 Dec;76(12):973-9.

28. Larkin P, Begley CM, Devane D. Women's preferences for childbirth experiences in the Republic of Ireland; a mixed methods study. BMC Pregnancy Childbirth [Internet]. 2017 Jan 10;17(1):19.

29. Sharma M, Dhungel S, Niroula S, Karki M. Knowledge and Acceptance of Labour Analgesia in Pregnant Women. J Nepal Health Res Counc. 2018 Oct 30;16(3):302-6.

30. Nabukenya MT, Kintu A, Wabule A, Muyingo MT, Kwizera A. Knowledge, attitudes and use of labour analgesia among women at a low-income country antenatal clinic. BMC Anesthesiol. 2015 Jul 7;15(1):98.

\section{ORCID and contributionship}

Martyna Rozek - 0000-0002-9848-0414 ${ }^{\text {A,B,C,D,E,F }}$

Zuzann Smiech - 0000-0002-4860-2508 B,C,D,E,F

Marcin Kolacz - 0000-0002-7126-5714 E,F

Dariusz Kosson - 0000-0002-1683-1154 ${ }^{\text {B,C,D,E,F }}$

\section{Conflict of interest}

Authors declare no conflict of interest.

\section{CORRESPONDING AUTHOR \\ Dariusz Kosson}

Department of Anaesthesiology and Intensive Care, Division of Teaching,

Medical University of Warsaw,

4 Lindley St., 02-005 Warsaw, Poland

tel. $+48-22-502-17-79$

fax. $+48-502-21-03$

e-mail: dariusz.kosson@wum.edu.pl

Received: 15.04 .2020

Accepted: 22.06 .2020

A - Work concept and design, B - Data collection and analysis, C - Responsibility for statistical analysis,

$\mathbf{D}$-Writing the article, $\mathbf{E}-$ Critical review, $\mathbf{F}-$ Final approval of the article 